\title{
Impact of Serial Hepatitis B Virus DNA on Hepatocellular Carcinoma Development in Patients with Liver Cirrhosis
}

\author{
Jung Hyun Kwon Jong Young Choi Jeong Won Jang Si Hyun Bae \\ Seung Kew Yoon Jin Mo Yang Nam Ik Han Chang Don Lee Young Seok Lee \\ Kyu Won Chung
}

Department of Internal Medicine, College of Medicine, WHO Collaborating Center on Viral Hepatitis,

The Catholic University of Korea, Seoul, Korea

\section{Key Words}

Hepatitis B virus DNA · Hepatocellular carcinoma • Liver

cirrhosis - Pattern of serial HBV DNA

\begin{abstract}
Objectives: We investigated the pattern of serial HBV DNA levels in known cirrhosis patients and its impact on the development of hepatocellular carcinoma (HCC). Methods: We analyzed a retrospective case/control study based on 352 HCC patients associated with HBV between 2005 and 2007. Prior to HCC development, 49 cirrhosis patients were tested for HBV DNA levels more than once a year (median 4 times) during the follow-up period. Ninety-eight consecutive cirrhosis patients without $\mathrm{HCC}$, matched for age, sex and $\mathrm{HBe}$ Ag status were included as controls. Eighty-three patients in both groups had undergone antiviral therapy. Results: In cirrhosis, the most common HBV DNA pattern was fluctuating (33.3\%), followed by persistently high $\left(\geq 10^{4}\right.$ copies $/ \mathrm{ml}$, $23.8 \%)$. Compared to a persistently low pattern $\left(<10^{4}\right.$ copies $/ \mathrm{ml})$, the relative risks of HCC in patients with persistently high and fluctuating patterns were 2.650 and 1.475. At multivariate analysis, a persistently high pattern was an independent risk factor for HCC (hazard ratio 3.135). Patients with
\end{abstract}

sustained HBV DNA suppression during antiviral therapy were less likely to develop HCC than those with viral breakthrough/nonresponse. Conclusions: This study showed that persistent suppression of HBV DNA is also important to prevent the development of HCC in known cirrhosis patients.

Copyright $\odot 2009$ S. Karger AG, Basel

\section{Introduction}

Several studies have consistently found significant associations between elevated HBV DNA levels and risk of liver cirrhosis and HCC [1]. In the REVEAL study, which is a large-scale population-based study [2], an elevated serum HBV DNA level ( $\geq 10^{4}$ copies/ml) was a strong predictor of death from chronic liver disease and cirrhosis and was second to cirrhosis in predicting death from HCC $[2,3]$. In addition, a prospective randomized trial using lamivudine for advanced liver diseases caused by HBV showed that successful antiviral therapy can prevent progression to cirrhosis or hepatocellular carcinoma (HCC) $[4,5]$.

However, unresolved questions concerning the relationship between HBV DNA level and HCC development

\section{KARGER}

Fax +41613061234 E-Mail karger@karger.ch www.karger.com (c) 2009 S. Karger AG, Basel

$0300-5526 / 10 / 0532-0111 \$ 26.00 / 0$

Accessible online at:

www.karger.com/int
Dr. Jong Young Choi

Seoul St. Mary's Hospital

505 Banpo-dong, Seocho-gu

Seoul 137-040 (Korea)

Tel. +82 22258 7565, Fax +82 23481 4025, E-Mail jychoi@ catholic.ac.kr 
remain. First, the majority of studies assess the serum HBV DNA level at a single time at study entry rather than at multiple time points or at the time of HCC development. However, there is little information on the changing pattern of the serial HBV DNA levels [6, 7], although recent data from the REVEAL-HBV study demonstrated that persistently elevated serum HBV DNA levels at more than two time points is a strong predictor of HCC risk [2, $8,9]$. Therefore, serial pattern analysis would be important in measurement of HCC risk; data from only two points including baseline and last follow-up are inadequate. Second, most epidemiologic studies included HBs Ag-positive patients with chronic hepatitis [2, 8-12]. Liver cirrhosis is a major risk factor for HCC, regardless of HBV DNA status $[3,13,14]$. In Asia, where HBV is highly endemic, individuals with cirrhosis are at an approximately 3 -fold greater risk for HCC than those with chronic hepatitis [15]. In addition, clinicians need to know how the HBV DNA titer may impact on a background of liver cirrhosis. Third, the impact of HBV DNA on HCC has usually been studied only in patients without antiviral therapy until now. However, clinicians still do not know the real pattern of the HBV DNA titer regardless of the antiviral response, although most hepatitis or cirrhosis patients have been treated with antiviral therapy for suppression of HBV DNA.

The aim of this study was to evaluate the longitudinal sequential levels of serum HBV DNA in known cirrhotic patients before the development of HCC, and to explore a possible relationship between the changing pattern of HBV DNA levels and HCC development with/without antiviral therapy.

\section{Materials and Methods}

\section{Patients}

All $352 \mathrm{HBV}$-related cirrhosis patients were diagnosed with HCC between January 2005 and December 2007 at our liver clinics and they were screened in this retrospective study. Among the 352 patients, 49 (13.9\%) consecutive cirrhosis patients who were tested for HBV DNA more than once a year and confirmed radiologically not to have HCC for at least 1 year prior to the development of HCC were finally enrolled. The reason for the small number of HCC patients with serial HBV DNA data is that most patients were referred from primary hospitals after detection of HCC, and these first-line care centers did not routinely assay HBV DNA levels. The proportion of modified UICC stage I and II were 42.9 and $51.0 \%$ in the enrolled HCC patients. The mean size of HCC was as small as $2.2 \mathrm{~cm}$.

All 172 HBV-related cirrhosis patients who had been followedup in our clinics without evidence of HCC between January 2005 and December 2007 were screened as controls. Among 172 pa- tients, a total of 98 patients (56.9\%) who were tested for HBV DNA more than twice prior to 2005-2007 and matched for age, gender and $\mathrm{HBe} \mathrm{Ag}$ status were recruited as controls (a ratio of 2:1 with respect to HCC patients). Cirrhosis was clinically defined by consistent findings using at least two of the following criteria: $\leq 150,000 \mathrm{U} / \mathrm{l}$ of platelets, a cirrhotic feature with splenomegaly on ultrasonography, or variceal change on gastrofibroscopy [16, 17]. Patients with hepatitis $\mathrm{C}$ co-infection, primary biliary cirrhosis, autoimmune hepatitis, significant alcohol intake, or Wilson's disease were excluded. Biochemical data on cirrhosis patients were obtained at 2- to 3-month intervals. We did not check HBV genotype, because genotype $\mathrm{C}$ was most prevalent in Korea. Ultrasonography was performed every 3 months and other imaging diagnostics were employed every year or whenever necessary. The diagnosis of HCC was made either histologically, or was based on an elevated serum alpha-fetoprotein $(>400 \mathrm{ng} / \mathrm{ml})$ level, with typical radiological findings from at least two imaging studies including ultrasonography, dynamic computed tomography, magnetic resonance imaging, and hepatic angiography [18].

The baseline demographics at the time of the first visit for cirrhosis are shown in table $1.57 .1 \%$ of the enrolled patients had their HBV DNA levels checked more than six times during the followup period. There were no differences in Child-Pugh grade classification or median HBV DNA level between the groups. The 'follow-up period' is the interval from the first visit for HBV-related cirrhosis, to the time of HCC development for the HCC group or the last visit for controls. In patients with HCC, the median time from the cirrhosis to development of the HCC was 37.8 months (range 12-71.1 months), and HBV DNA levels were checked 4 times (median, range 2-12 analyses). In the control cirrhosis group, the median follow-up time was 67.8 months (range 17.9-84.0 months) and HBV DNA levels were assayed 5 times (median, range $2-12$ analyses).

Twenty-nine patients (59.2\%) in the HCC group and 54 patients $(55.1 \%)$ in the control group were treated with antiviral agents. Antiviral therapy of these patients was started after the enrollment of study. The mean duration of antiviral therapy was 37.2 and 47.0 months in the HCC and the control cirrhosis groups, respectively. The antiviral drugs used were as follows: 49 (59.0\%) patients received only lamivudine, $19(22.9 \%)$ patients taking lamivudine switched to adefovir, 4 (4.8\%) patients prescribed lamivudine combined with adefovir, $6(7.2 \%)$ patients taking interferon switched to lamivudine, $2(2.4 \%)$ patients were prescribed adefovir, and 3 (3.6\%) patients were on entecavir. Response to antiviral therapy defined an undetectable HBV DNA level by realtime PCR. Sustained viral response was defined as being without viral breakthough after antiviral treatment.

The study protocol was conducted with the approval of the institutional review board of Seoul St. Mary's Hospital.

Changing Pattern of Serum HBV DNA Levels

Serum HBV DNA levels were measured using either the VERSANT HBV DNA 3.0 assay (Bayer HealthCare-Diagnostics; Tarrytown, N.Y., USA) or a quantitative real-time PCR method (ABI Prism 7000; Applied Biosystems, Darmstadt, Germany), in accordance with the manufacturer's instructions. The limit of detection for the VERSANT HBV DNA 3.0 assay was 2,000 copies $/ \mathrm{ml}$ and that of the real-time PCR method was 28 copies $/ \mathrm{ml}$.

The changing patterns of sequential HBV DNA titers were arbitrarily classified as follows: Type 1 was a persistently high 


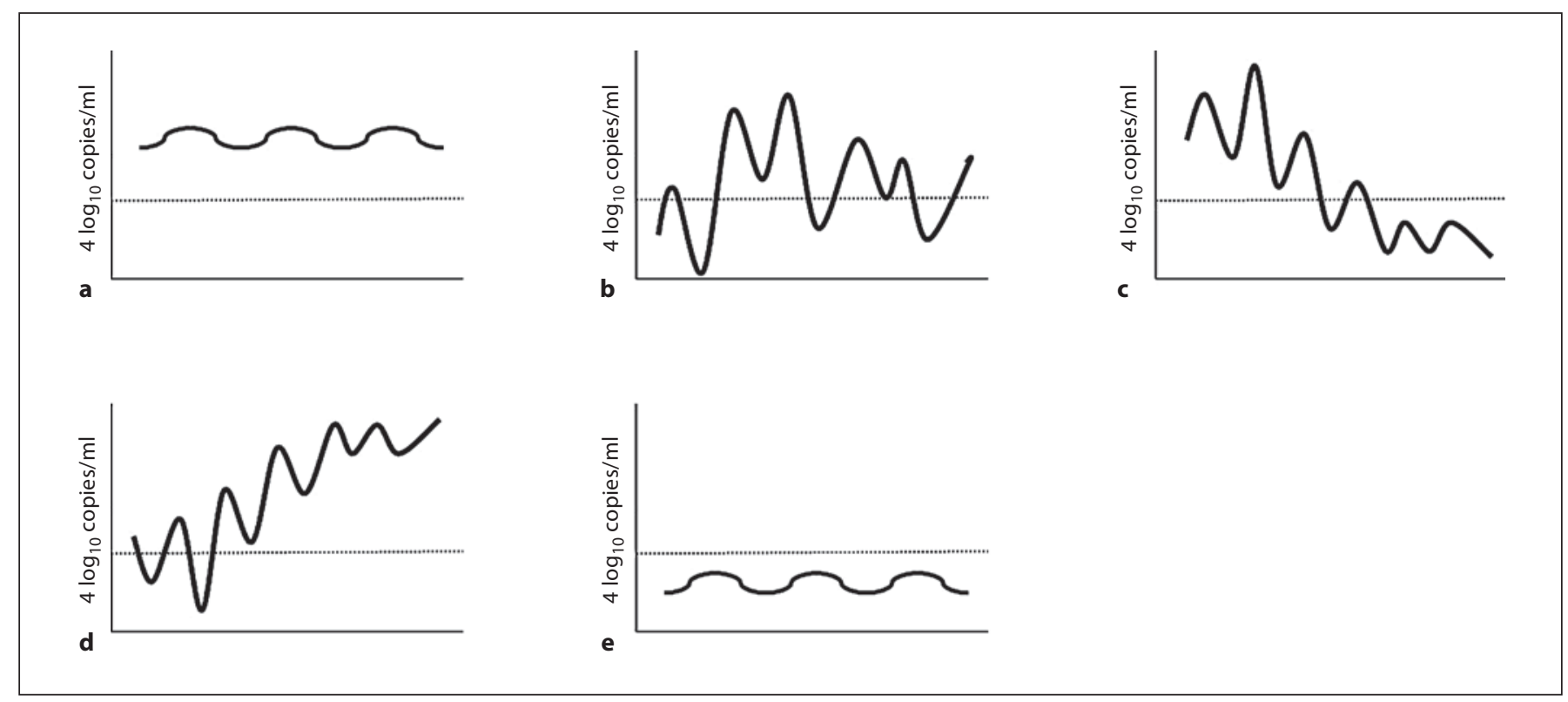

Fig. 1. The changing patterns of longitudinal HBV DNA levels in cirrhosis patients before HCC development were classified as follows. a Type 1, a persistently high pattern. b Type 2, a fluctuating pattern. c Type 3, a decreasing pattern. d Type 4, an increasing pattern. e Type 5, a persistently low pattern. The reference line is 4 $\log _{10}$ copies/ml.

Table 1. Baseline characteristics at the time of first visit of HBV-related cirrhosis

\begin{tabular}{|c|c|c|c|c|}
\hline & $\begin{array}{l}\text { Liver cirrhosis to HCC } \\
(\mathrm{n}=49)\end{array}$ & $\begin{array}{l}\text { Liver cirrhosis to } \\
\text { liver cirrhosis }(\mathrm{n}=98)\end{array}$ & $\begin{array}{l}\text { Total } \\
(\mathrm{n}=147)\end{array}$ & $\mathrm{p}$ value \\
\hline Age, years & $55.3 \pm 9.8$ & $52.2 \pm 8.2$ & $53.3 \pm 8.8$ & 0.061 \\
\hline Male/female (male \%) & $37 / 12(75.5)$ & $63 / 35(64.3)$ & $100 / 47(68.0)$ & 0.169 \\
\hline HBe Ag status, yes/no (yes \%) & $23 / 26(46.9)$ & $52 / 43(54.7)$ & $75 / 69(52.1)$ & 0.803 \\
\hline Child-Pugh grade, $\mathrm{A} / \mathrm{B} / \mathrm{C}$ & $44 / 5 / 0$ & $87 / 8 / 3$ & $131 / 13 / 3$ & 0.437 \\
\hline Alanine aminotransferase, $\mathrm{U} / \mathrm{l}$ & $54(18-464)$ & $43(19-955)$ & $47(11-876)$ & 0.215 \\
\hline Total bilirubin, mg/dl & $1.2 \pm 0.6$ & $1.5 \pm 1.5$ & $1.4 \pm 1.3$ & 0.064 \\
\hline Albumin, g/dl & $3.8 \pm 0.5$ & $3.8 \pm 0.6$ & $3.8 \pm 0.6$ & 0.430 \\
\hline Platelets, $\times 10^{3} / \mu \mathrm{l}$ & $118.9 \pm 49.7$ & $122.9 \pm 50.5$ & $121.6 \pm 50.1$ & 0.656 \\
\hline Prothrombin time, INR & $1.2 \pm 0.3$ & $1.2 \pm 0.3$ & $1.2 \pm 0.3$ & 0.584 \\
\hline Alfa-fetoprotein, $\mathrm{ng} / \mathrm{ml}$ & $8.7(0.2-473.5)$ & $5.3(0.01-472.1)$ & $5.8(0.01-473.5)$ & 0.293 \\
\hline HBV DNA, copies/ml & $2.7 \times 10^{6}\left(1.0-3.3 \times 10^{8}\right)$ & $3.2 \times 10^{5}\left(1-1.5 \times 10^{9}\right)$ & $1.2 \times 10^{6}\left(0-1.5 \times 10^{9}\right)$ & 0.342 \\
\hline
\end{tabular}

pattern $\left(\geq 10^{4}\right.$ copies/ml) of HBV DNA with between-measurements change of $1-2 \log _{10}$ DNA copies/ml. Type 2 was a fluctuating pattern of HBV DNA titer over the range of $2-3 \log _{10}$ DNA copies $/ \mathrm{ml}$ based on $10^{4}$ copies $/ \mathrm{ml}$. Type 3 was a decreasing pattern of HBV DNA titer $\left(<10^{4}\right.$ copies $\left./ \mathrm{ml}\right)$. Type 4 was an increasing pattern of HBV DNA titer $\left(\geq 10^{4}\right.$ copies $\left./ \mathrm{ml}\right)$. Type 5 was a persistently low pattern of HBV DNA titer $\left(<10^{4}\right.$ copies $\left./ \mathrm{ml}\right)$ (fig. 1).

Pattern of Serial Hepatitis B Virus DNA
Statistical Analysis

Basal characteristics are expressed as means \pm SDs or medians (with ranges), and the relevant numbers of patients are given. Continuous variables were compared using Student's t test or the Mann-Whitney U test as appropriate. Factors affecting HCC development were identified on univariate and multivariate analysis using Cox' proportional hazard model. All analyses were twotailed with an $\alpha$ of 0.05 . All calculations were performed with SPSS (14th ed.; SPSS; Chicago, Ill., USA). 
Table 2. The five changing pattern of serum HBV DNA titer after diagnosis of cirrhosis

\begin{tabular}{|c|c|c|c|c|c|c|}
\hline & \multicolumn{2}{|l|}{ Total } & \multicolumn{2}{|c|}{ Antiviral therapy } & \multicolumn{2}{|l|}{ No therapy } \\
\hline & $\mathrm{HCC}(\mathrm{n}=49)$ & control $(\mathrm{n}=98)$ & $\operatorname{HCC}(n=29)$ & control $(\mathrm{n}=54)$ & $\operatorname{HCC}(\mathrm{n}=20)$ & control $(n=44)$ \\
\hline Type 1 & $14(28.6)$ & $21(21.4)$ & $4(13.8)$ & $7(13.0)$ & $10(50.0)$ & $14(31.8)$ \\
\hline Type 2 & $17(34.7)$ & $32(32.7)$ & $15(51.7)$ & $21(38.9)$ & $2(10.0)$ & $11(25.0)$ \\
\hline Type 3 & $5(10.2)$ & $13(13.3)$ & $2(6.9)$ & $13(24.1)$ & $3(15.0)$ & 0 \\
\hline Type 4 & $6(12.2)$ & $13(13.3)$ & $3(10.3)$ & $4(7.4)$ & $3(15.0)$ & $9(20.5)$ \\
\hline Type 5 & $7(14.3)$ & $19(19.4)$ & $5(17.2)$ & $9(16.7)$ & $2(10.0)$ & $10(22.7)$ \\
\hline $\mathrm{p}$ value & \multicolumn{2}{|c|}{0.827} & \multicolumn{2}{|c|}{0.406} & \multicolumn{2}{|c|}{0.030} \\
\hline
\end{tabular}

Table 3. Development of HCC from liver cirrhosis according to the cut-off $10^{4}$ copies $/ \mathrm{ml}$ in HBV DNA load

\begin{tabular}{|c|c|c|c|c|c|c|}
\hline \multirow{2}{*}{$\begin{array}{l}\text { HBV DNA } \\
\text { copies/ml }\end{array}$} & \multicolumn{2}{|l|}{ Total } & \multicolumn{2}{|c|}{ Antiviral therapy } & \multicolumn{2}{|l|}{ No therapy } \\
\hline & $\operatorname{HCC}(n=49)$ & control $(\mathrm{n}=98)$ & $\operatorname{HCC}(\mathrm{n}=29)$ & control $(\mathrm{n}=54)$ & $\operatorname{HCC}(n=20)$ & control $(n=44)$ \\
\hline Low/decreasing $\left(<10^{4}\right)$ & $18(36.7)$ & $52(53.1)$ & $13(44.8)$ & $36(66.7)$ & $5(25.0)$ & $16(36.4)$ \\
\hline Elevated $\left(\geq 10^{4}\right)$ & $31(63.3)$ & $46(46.9)$ & $16(55.2)$ & $18(33.3)$ & $15(75.0)$ & $28(63.6)$ \\
\hline
\end{tabular}

\section{Results}

\section{Changing Pattern of Serial HBV DNA Levels and}

Effects of Antiviral Treatment

In both the HCC and control groups, type 2 (the fluctuating pattern) was the most common pattern of $\mathrm{HBV}$ DNA levels, followed by type 1 and type 5 patterns (table 2). In patients without antiviral therapy, the proportion showing the persistently high HBV DNA pattern (type 1) was higher in the HCC group than in the control group (50.0 vs. $31.8 \%$ ). Also, the proportion with the persistently low HBV DNA pattern (type 5) was higher in the control cirrhosis group than in the HCC group (22.7 vs. $10.0 \%)$. There was a significant difference of DNA pattern between the two groups without antiviral therapy $(\mathrm{p}=$ 0.030). In patients receiving antiviral therapy, the difference between the HCC and control group was less obvious $(\mathrm{p}=0.406)$. The proportion with the fluctuation pattern (type 2) and the decreasing pattern (type 3) was high and low in the HCC group compared to the control group (51.7 vs. $38.9 \%$, 24.1 vs. $6.9 \%$ ), respectively. However, the proportion with the persistently low HBV DNA (type 5) was similar between the two groups (17.2 vs. 16.7\%).

We integrated the patterns of types 1,4 versus 3, 5 (patients with type 2 were divided by the last DNA level), and then compared the elevated HBV DNA $\geq 10^{4}$ copies $/ \mathrm{ml}$ versus low/decreasing HBV DNA. The proportion with an elevated HBV DNA pattern in the HCC group was higher than in the controls (63.3 vs. $46.9 \%, \mathrm{p}=0.062$ ) with or without the antiviral therapy (table 3 ).

When overall responses of antiviral therapy were examined, the rates of HBV DNA suppression in the HCC group and the control cirrhosis cases were similar (62.1 vs. $75.9 \%)$ ( $p=0.184)$. However, the incidence rates of breakthrough after HBV DNA suppression in the HCC and control groups were $12(66.7 \%)$ and 15 (36.6\%) $(\mathrm{p}=0.033)$, respectively. The likelihood of developing HCC was significantly less for patients with sustained virological response than patients with virological breakthrough/or nonresponders $(p=0.017)$ (fig. 2).

\section{Risk of HCC with Changing Patterns of HBV DNA}

The fluctuation of HBV DNA levels was very dynamic regardless of HCC development or cirrhosis groups (fig. 3). The overall incidence rates of HCC in patients showing the various patterns were 10.6, 11.4, 3.4, 4.1 and $4.8 \%$ for pattern types $1,2,3,4$, and 5 , respectively (table 2). Compared with type 5, the relative risks for HCC in patients with types 1 and 2 were $2.650(\mathrm{p}=0.037)$ and 1.475 ( $p=0.387)$, respectively (table 4$)$. In the antiviral therapy group, the relative risks for HCC in type 2 patients were 0.623 and 1.345 compared with types 1 and 5, respectively. In patients not receiving antiviral therapy, the relative risks for HCC in type 1 cases were 3.585 and 
Fig. 2. Cumulative incidence of HCC during the follow-up period in the cirrhotic patients receiving antiviral therapy according to sustained virological response and breakthrough/or nonresponder ( $\mathrm{p}=0.017$, by log-rank test). SVR = Sustained virological response.
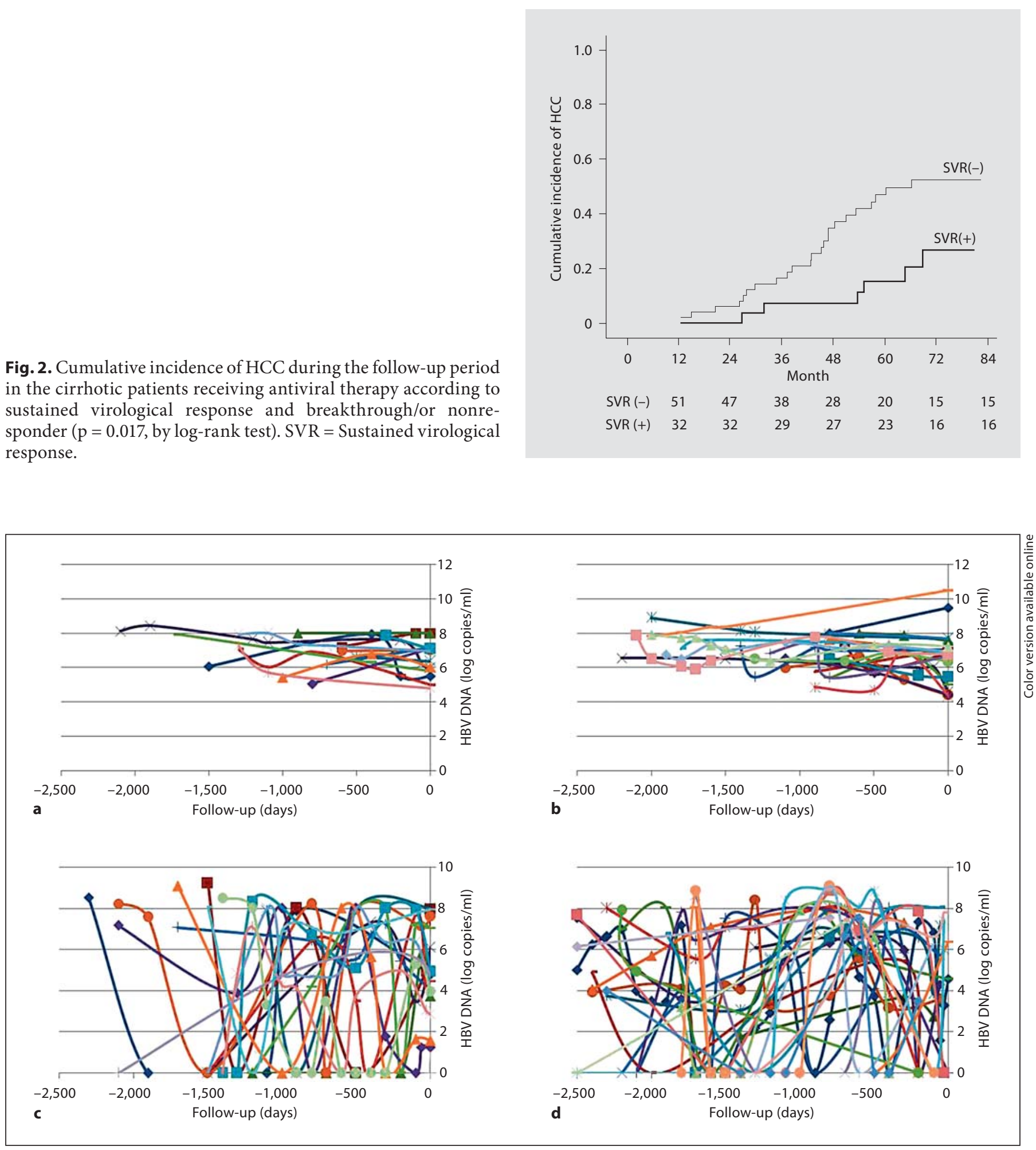

Fig. 3. Common patterns (types 1 and 2) of HBV DNA expression in both groups. a The persistently high pattern (type 1) of HBV DNA expression in the HCC group. b The persistently high pattern (type 1) of HBV DNA expression in control cirrhosis patients. c The fluctuation pattern (type 2) of HBV DNA in the HCC group. d The fluctuation pattern (type 2) of HBV DNA in control cirrhosis cases. ' 0 day' defines the time of HCC development for HCC group cases or the same time point for control cirrhosis group patients. 
Table 4. Factors identified on univariate and multivariate analysis as influencing hepatocellular carcinoma development

\begin{tabular}{|c|c|c|c|c|c|c|}
\hline & \multicolumn{3}{|c|}{ Univariate analysis } & \multicolumn{3}{|c|}{ Multivariate analysis } \\
\hline & HR & $95 \% \mathrm{CI}$ & $\mathrm{p}$ & HR & $95 \% \mathrm{CI}$ & $\mathrm{p}$ \\
\hline Age & 1.032 & $0.998-1.067$ & 0.064 & & & \\
\hline Male sex & 1.539 & $0.802-2.954$ & 0.195 & & & \\
\hline $\mathrm{HBe} \mathrm{Ag}(+)$ & 1.139 & $0.620-2.093$ & 0.675 & 0.946 & $0.503-1.781$ & 0.864 \\
\hline Antiviral therapy & 1.009 & $0.571-1.785$ & 0.974 & 1.109 & $0.570-2.158$ & 0.761 \\
\hline Child-Pugh B or C & 0.946 & $0.704-1.271$ & 0.713 & 1.132 & $0.374-3.425$ & 0.826 \\
\hline Type 1 & 2.650 & $1.061-6.617$ & 0.037 & 3.135 & $1.182-8.319$ & 0.022 \\
\hline Type 2 & 1.475 & $0.611-3.559$ & 0.387 & 1.449 & $0.584-3.593$ & 0.423 \\
\hline Type 3 & 1.510 & $0.478-4.768$ & 0.482 & 1.572 & $0.486-5.079$ & 0.450 \\
\hline Type 4 & 1.327 & $0.446-3.951$ & 0.611 & 1.486 & $0.475-4.647$ & 0.496 \\
\hline Type 5 & \multicolumn{2}{|c|}{1.0 (reference) } & 1.0 (reference) & & & \\
\hline
\end{tabular}

Type is a changing pattern of HBV DNA; type 1 , a persistently high pattern $\left(\geq 10^{4}\right.$ copies $\left./ \mathrm{ml}\right)$, type 2 , a fluctuating pattern, type 3 , a decreasing pattern, type 4 , an increasing pattern, and type 5 , a persistently low pattern $\left(<10^{4} \mathrm{copies} / \mathrm{ml}\right)$.

$\mathrm{HR}=$ Hazard ratio; $\mathrm{CI}=$ confidence interval.

3.689 , compared with type 2 and type 5 patients, respectively.

On univariate analysis, the changing pattern of type 1 cases was associated with an increased risk of HCC (table 4). On multivariate analysis, the type 1 pattern, compared to the type 5 pattern, remained an independent risk factor associated with HCC, with a hazard ratio of 3.135 (95\% CI, 1.182-8.319, $\mathrm{p}=0.022$ ).

\section{HCC in Patients with Persistently Low Titers of HBV DNA}

Seven patients (14.3\%) in the HCC group and 19 patients (19.4\%) in the control cirrhosis group showed the type 5 pattern. Patients in this low viral load group were similar in mean serum alanine transferase (ALT) level, albumin concentration, total bilirubin level, prothrombin time, and age between the HCC group and control cirrhosis cases. The patients with low viral load were all Child-Pugh A class. The proportion of patients with definitive regenerating nodules over $5 \mathrm{~mm}$ in diameter upon regular ultrasonography was higher in the HCC group than in the controls [3/7 (42.8\%) vs. 5/18 (27.7\%), respectively $(\mathrm{p}=0.340)]$.

\section{Discussion}

The present study showed that persistently high expression of HBV DNA (type 1) was a significant risk factor for HCC development, especially in liver cirrhosis, compared with other serial DNA patterns. Although the REVEAL-HBV study reported the importance of HBV DNA load at entry time and/or last follow-up in patients without antiviral therapy, clinicians hope to know DNA events with/without antiviral therapy over several years because HBV DNA assayed at only two time points cannot yield an overall picture. Recently, a significant proportion of patients with HBV-related liver cirrhosis have received or have been receiving nucleos(t)ide analogues. So, our study thus tried to answer questions about patterns of DNA expression during long-term follow-up depending on the antiviral therapy. As figure 3 shows, the serum HBV DNA level in each of the groups varied in a highly dynamic manner, reflecting viral suppression by antiviral drugs and breakthrough or spontaneous activation of HBV. In this study, we classified 5 types by global HBV DNA expression patterns rather than using only entry and last follow-up HBV DNA measurements. Such global patterns reflect the real impact of HBV DNA levels on the risk of HCC development. Despite the retrospective nature of the study, this matched case-control work clearly demonstrated the importance of the changing pattern of HBV DNA in the development of HCC among patients with liver cirrhosis.

Expectedly, the proportions of patients with various HBV DNA patterns differed in cases receiving or not receiving antiviral therapy. In the antiviral therapy group, the proportions of fluctuation pattern (means breakthrough) and increasing (means non-response) pattern in the HCC group were higher than in the control cir- 
rhosis group. Furthermore, we showed that a sustained viral response to antiviral therapy will be less likely in patients who will develop HCC after antiviral treatment compared to those who do not develop HCC after treatment. Among no antiviral therapy, the proportion of persistently high pattern and low pattern in the HCC group was significantly higher and lower, respectively. This result suggests the significance of a sustained high level of HBV DNA for the development of HCC in the cirrhosis patients even with normal levels of liver enzyme and thus no antiviral therapy. This is reminiscent of the clinical situation. These results are consistent with previous reports showing that sustained responders to lamivudine therapy are at reduced risk of HCC compared with nonresponders, or to untreated patients $[4,5]$. Our study reflects the impact of sustained virological response for antiviral therapy on the prevention of developing HCC. However, our retrospective study had too small a number to suggest the usefulness of antiviral treatment in liver cirrhosis for preventing the HCC. This is the consistent with the recent report by Chan et al. [19]. In that study [19], among patients with antiviral treatment, the differences in trough HBV DNA levels between the HCC and control patients were less obvious, although among patients without antiviral treatment, HCC patients had significantly higher trough HBV DNA levels than the control patients. They were not able to match the cirrhosis status and treatment status, although the importance of the trough HBV DNA level remained significant after adjustment for the treatment factor. Similarly, we could not match all the proportions of patients receiving antiviral treatment in the HCC and control groups.

In our work, the overall incidence of HCC in the sustained low viral load group was $4.8 \%$ compared with $10.6 \%$ in the high viral load group during a median follow-up time of 48 months. Why do cirrhosis patients develop HCC even if they have a low viral load? In a wellknown study by Liaw et al. [4], lamivudine therapy in advanced liver disease definitively suppressed progression of cirrhosis to decompensation. However, the suppression of HCC development by lamivudine therapy was not as definitive as reduction of disease progression. This means that HCC development in cirrhosis is associated not only with high viral load, but also with cirrhosis per se. Another characteristic of cirrhosis is that cirrhotic patients develop HCC over a relatively short interval, in contrast to chronic hepatitis patients. Kobayashi et al. [20] reported that $19 \%$ of nodules in consecutive cirrhosis patients with hepatic nodules, but without HCC, devel- oped into HCC over a median duration of 2.8 years. Screening for HCC is usually performed by ultrasonography, and follow-up of hepatic nodules to monitor the development of HCC will be necessary. Several previous studies have also reported that cirrhosis per se was a significant risk factor for HCC [13-15].

This study has several limitations. First, it is a retrospective case-control study. Thus, there will be selection bias. Although the degree of liver cirrhosis at baseline was similar in both groups, the actual cumulative incidence of HCC was not estimated in view of the retrospective study. Second, very low HBV DNA ( $<200$ copies/ml) levels were not explored in apparently virus-free patients. However, clinical evidence would suggest that the risk of HCC was not very significant in patients with viral loads less than $10^{4}$ copies $/ \mathrm{ml}$. The limit of HBV DNA level used to classify the DNA patterns was thus defined as $10^{4} \mathrm{cop}$ ies $/ \mathrm{ml}$. Third, the number of patients was too small to draw conclusions especially about types 3 and 4 . Some patients showed borderline features among the five DNA pattern types. Confusion about the pattern of HBV DNA was possible, depending on the frequency and interval of HBV DNA testing. So, some type 2 s may be mistaken as type 1 if the trough levels are missed. However, the median duration of follow-up was about 4.6 years in both the HCC and control cirrhosis groups, and serial HBV DNA levels were checked about five times (a median value) in all patients. We analyzed the integrating pattern of five types and got similar results. Also, the fluctuating pattern (type 2) which was not simply grouped into the elevated or decreased pattern was the most common pattern for cirrhosis patients in clinical practice. Fourth, the ALT level was not evaluated in the present study. However, in the previous study about the pattern of HBV DNA and ALT level, the value of cancer prediction was much higher in the assay of HBV DNA than that of ALT $[6,7]$.

Our results suggest that persistent suppression of $\mathrm{HBV}$ DNA with antiviral therapy is important during monitoring of cirrhosis patients for the prevention of HCC development, similar to the care required by chronic hepatitis patients. Even in patients with persistently low HBV DNA titers, those with regenerating nodules should be carefully observed for HCC development. These findings should be confirmed by a large-scale prospective study. Future work is needed to stratify the HCC risk considering both serial HBV DNA patterns and virological responses to antiviral therapy. 


\section{Acknowledgements}

This work was funded by a grant (A050021, Liver Cirrhosis Clinical Research Center) of the Korea Health 21 Research and Development Project, Ministry of Health and Welfare, Republic of Korea.
All authors contributed significantly to this work; J.H. Kwon, J.Y. Choi, J.W. Jang, S.H. Bae, S.K. Yoon, J.M. Yang, N.I. Han, C.D. Lee, Y.S. Lee and K.W. Chung designed and performed the research. J.H. Kwon and J.Y. Choi analyzed the data and wrote the paper.

\section{References}

1 Chen CJ, Yang HI, Iloeje UH: Hepatitis B virus DNA levels and outcomes in chronic hepatitis B. Hepatology 2009;49:S72-S84.

$\checkmark 2$ Chen CJ, Yang HI, Su J, Jen CL, You SL, Lu SN, Huang GT, Iloeje UH: Risk of hepatocellular carcinoma across a biological gradient of serum hepatitis B virus DNA level. JAMA 2006;295:65-73.

- 3 Iloeje UH, Yang HI, Jen CL, Su J, Wang LY, You SL, Chen CJ: Risk and predictors of mortality associated with chronic hepatitis B infection. Clin Gastroenterol Hepatol 2007;5: 921-931.

-4 Liaw YF, Sung JJ, Chow WC, Farrell G, Lee $\mathrm{CZ}$, Yuen H, Tanwandee T, Tao QM, Shue K, Keene ON, Dixon JS, Gray DF, Sabbat J: Lamivudine for patients with chronic hepatitis $\mathrm{B}$ and advanced liver disease. N Engl J Med 2004;351:1521-1531

5 Di Marco V, Marzano A, Lampertico P, Andreone P, Santantonio T, Almasio PL, Rizzetto $\mathrm{M}$, Craxi A: Clinical outcome of HBeAgnegative chronic hepatitis $B$ in relation to virological response to lamivudine. Hepatology 2004;40:883-891.

-6 Ikeda K, Arase Y, Kobayashi M, Someya T, Saitoh S, Suzuki Y, Suzuki F, Tsubota A, Akuta N, Kumada H: Consistently low hepatitis $B$ virus DNA saves patients from hepatocellular carcinogenesis in HBV-related cirrhosis: a nested case-control study using 96 untreated patients. Intervirology 2003;46: 96-104.

-7 Mahmood S, Niiyama G, Kamei A, Izumi A, Nakata K, Ikeda $H$, Suehiro M, Kawanaka M, Togawa K, Yamada G: Influence of viral load and genotype in the progression of hepatitis B-associated liver cirrhosis to hepatocellular carcinoma. Liver Int 2005;25:220-225.
8 Chen CF, Yang HI, Iloeje UH, Su J, Jen CL, You SL, CH C: Changes in serum HBV-DNA level using a trajectory model to predict the risk of HCC in chronic hepatitis B patients: The R.E.V.E.A.L-HBV study. Hepatol Int 2008;2:A188.

$\checkmark 9$ Chen CJ, Yang HI, Su J, Jen CL, You SL, Chen CF, UH I: Serial monitoring of viral load and serum alanine aminotransferase level and the risk of hepatocellular carcinoma (HCC): R.E.V.E.A.L.-HBV study update. J Hepatol 2008;48:S61.

10 Chan HL, Tse CH, Mo F, Koh J, Wong VW, Wong GL, Lam Chan S, Yeo W, Sung JJ, Mok TS: High viral load and hepatitis B virus subgenotype ce are associated with increased risk of hepatocellular carcinoma. J Clin Oncol 2008;26:177-182.

-11 Fung J, Yuen MF, Yuen JC, Wong DK, Lai CL: Low serum HBV DNA levels and development of hepatocellular carcinoma in patients with chronic hepatitis B: A case-control study. Aliment Pharmacol Ther 2007;26: 377-382.

-12 Yuen MF, Tanaka Y, Shinkai N, Poon RT, But DY, Fong DY, Fung J, Wong DK, Yuen JC, Mizokami M, Lai CL: Risk for hepatocellular carcinoma with respect to hepatitis B virus genotypes $b / c$, specific mutations of enhancer ii/core promoter/precore regions and HBV DNA levels. Gut 2008;57:98-102.

13 Simonetti RG, Camma C, Fiorello F, Politi F, D’Amico G, Pagliaro L: Hepatocellular carcinoma: a worldwide problem and the major risk factors. Dig Dis Sci 1991;36:962-972.
14 Chan HL, Hui AY, Wong ML, Tse AM, Hung LC, Wong VW, Sung JJ: Genotype C hepatitis $B$ virus infection is associated with an increased risk of hepatocellular carcinoma. Gut 2004;53:1494-1498

-15 Fattovich G, Stroffolini T, Zagni I, Donato F: Hepatocellular carcinoma in cirrhosis: Incidence and risk factors. Gastroenterology 2004;127:S35-S50

16 Iloeje UH, Yang HI, Su J, Jen CL, You SL, Chen CJ: Predicting cirrhosis risk based on the level of circulating hepatitis B viral load. Gastroenterology 2006;130:678-686.

17 Lee JI, Park HJ, Lee JW, Kim YS, Jeong S, Lee DH, Kim HG, Shin YW, Kwon KS: Pretreatment alanine transaminase level may not be the most important predictor of hepatitis B envelope antigen loss in the older patient. Liver Int 2009;29:231-236.

18 Jang JW, Choi JY, Bae SH, Yoon SK, Woo HY, Chang UI, Kim CW, Nam SW, Cho SH, Yang JM, Lee CD: The impact of hepatitis B viral load on recurrence after complete necrosis in patients with hepatocellular carcinoma who receive transarterial chemolipiodolization: implications for viral suppression to reduce the risk of cancer recurrence. Cancer 2007; 110:1760-1767.

19 Chan HL, Wong VW, Wong GL, Chim AM, Lai LH, Sung JJ: Evaluation of impact of serial hepatitis B virus DNA levels on development of hepatocellular carcinoma. J Clin Microbiol 2009;47:1830-1836.

20 Kobayashi M, Ikeda K, Hosaka T, Sezaki H, Someya T, Akuta N, Suzuki F, Suzuki Y, Saitoh S, Arase Y, Kumada H: Dysplastic nodules frequently develop into hepatocellular carcinoma in patients with chronic viral hepatitis and cirrhosis. Cancer 2006;106: 636-647. 